\title{
The Stalin Cult as Political Religion
}

\author{
Graeme Gill
}

check for updates

Citation: Gill, Graeme. 2021. The Stalin Cult as Political Religion. Religions 12: 1112. https://doi.org/ 10.3390/rel12121112

Academic Editor: Xavier Marquez

Received: 16 November 2021 Accepted: 13 December 2021 Published: 17 December 2021

Publisher's Note: MDPI stays neutral with regard to jurisdictional claims in published maps and institutional affiliations.

Copyright: (C) 2021 by the author. Licensee MDPI, Basel, Switzerland. This article is an open access article distributed under the terms and conditions of the Creative Commons Attribution (CC BY) license (https:/ / creativecommons.org/licenses/by/ $4.0 /)$.
Department of Government and International Relations, The University of Sydney, Sydney 2006, Australia; graeme.gill@sydney.edu.au

\begin{abstract}
Political religion is a concept that gained prominence around the middle of the twentieth century, being associated for many with the idea of a totalitarian regime. Political religion was seen as a secular ideology whose followers took it up with the enthusiasm and commitment normally associated with adherence to religion. Comprising liturgy, ritual and the sacralization of politics, it created a community of believers, and usually had a transcendental leadership and a millennial vision of a promised future. This paper will explore the utility of this concept for understanding leader cults in authoritarian regimes. Such cults have been prominent features of authoritarian regimes but there is little agreement at the conceptual level about how they should be understood. One of the most powerful of such cults was that of Joseph Stalin in the Soviet Union from 1929 to 1953. This paper analyses this cult in terms of liturgy and ritual and concludes that despite some aspects that are common between the cult and religion, most ritualistic aspects of religion find no direct counterpart in the cult.
\end{abstract}

Keywords: political religion; leader cult; liturgy; ritual; Stalin; Soviet Union

\section{Introduction}

The idea of political religion has been around for some time, although it reached its height of acceptance in the middle of the twentieth century when the notion of totalitarianism was popular as a framework for understanding the Nazi German, fascist Italian and communist Soviet regimes (Voegelin [1938] 1986). The link between totalitarianism and political religion was emphasised in the title of an academic journal that marked a new surge of interest in totalitarianism in the 1990s, Totalitarian Movements and Political Religions, begun in 2000 and renamed Politics, Religion and Ideology in 2011. The essence of political religion as understood by those who used the term (for example, (Griffin 2005; Kurz 2009); paradoxically, the main theorists of totalitarianism did not use this as an important analytical concept; for example, (Arendt [1951] 1986; Friedrich and Brzezinski [1956] 1965; Schapiro 1972; also see Maier 2007)) was a secular ideology whose followers took it up with the enthusiasm and commitment normally seen in the adherents of religion. It usually had a transcendent leadership, a millennial vision of the promised future, and gave a real sense of belonging to its adherents; it created a community of believers (similar to Tikhomirov's "cult community", (Tikhomirov 2021, pp. 120-42)), usually with an intolerance of outsiders, the non-believers. According to an Italian scholar of fascist Italy, Emilio Gentile, political religion comprised liturgy, ritual and the sacralization of politics. (Cited in Roberts 2020, p. 59) This paper will explore the utility of political religion as a concept for understanding leader cults in authoritarian polities through the case of the cult of Stalin in the USSR.

The cult burst onto the Soviet scene in December 1929 to mark Stalin's fiftieth birthday (Apor et al. 2004; Brooks 2000; Heller and Plamper 2004; Plamper 2012; Pisch 2016). Projected through the mass media, cinema, art, statuary, posters, literature, and a wide range of artefacts, the cult came to dominate Soviet public culture, especially from the mid1930s until Stalin's death in 1953. The cult fluctuated over time in terms of its dominance of the public scene (Plamper 2012, pp. 227-33) and the images that it projected, but its principal message- the essential goodness and wisdom of the dominant Stalin-did not 
waver. Additionally linked to the cult but less studied were various liturgical or ritualist activities; and in order to evaluate the cult as political religion, these must be included in the analysis.

The clearest way in which the cult could be seen in religious terms is through the relationship it sought to create between the principal of the cult, Joseph Stalin, and his followers. The essence of this was the attempt to create a relationship between the two that can best be described as charismatic (Weber [1922] 1978, pp. 241-55 and 1111-57). In the true charismatic relationship, the followers surrender all independent initiative and judgement, blindly following the leader and doing whatever he says. The leader's word is mandatory, binding and unquestionable. The basis of this sort of commitment is that the leader promises to lead the followers to some promised land, in Stalin's case to communism, just as the religious leader in eschatological religions promised salvation through following "the word". The reverence with which Stalin's speeches and writings were treated and the injunction to continually be guided by them was similar to the attitude to the holy books in the eschatological religions. Complete and unquestioning commitment to the "word" was the key to the afterlife, and it was the strength of that commitment that was the basis of the claim for charisma. The cult sought to bind together the believers into an emotional community in which not merely acquiescence but total commitment was demanded. In practice, it is not clear to what extent the intensity of commitment did actually match that required to claim that a charismatic relationship had been created, but this was clearly the intent of the cult. However, even if such a relationship did not emerge, the attempt to create it did structure action and thereby produce a liturgy. This liturgy, or framework of action, applied to two groups: the immediate intimates of the principal of the cult, and the mass following.

\section{Cultist Liturgy}

Perhaps the most compelling aspect of this was the way the cult created a framework for thinking and understanding. Crucial to this was the activities of a series of people behind the scenes. These were not the political intimates of Stalin, but the "technicians" who shaped the principal infrastructural struts of the cult. It was these people who designed and policed the pictures, posters, statues and other forms of visual representation of Stalin. They were not all concentrated in one office, but distributed throughout all of the main institutions of cultural production-artistic associations, publishing houses, newspapers, journals, media and cinema, and educational institutions-as well as leading party and state bodies (Plamper 2012, chp. 5). People worked to produce the images that constituted the cult, often working under direct contract from official artistic/cultural organisations (Plamper 2012, pp. 168-69). Precise regulations governed the way Stalin was to be presented in visual form ('Struggling for Stalin's Soul': The Leader Cult and the Balance of Social Power in Stalin's Inner Circle in (Heller and Plamper 2004, p. 166)). From early in the 1930s, this all took place under the watchful eye of Stalin's personal office, headed from 1930 by Aleksandr Poskrebyshev (Plamper 2012, pp. 129-34). Notwithstanding his claimed opposition to the cult (for example, Feuchtwanger 1937, pp. 76-77; Plamper 2012, pp. 120-27), Stalin himself took an active part in the shaping of the cultist message, especially regarding the publication of his writings, to ensure as much as possible the correct image and tone were projected (Plamper 2012, pp. 133-37). Such involvement should not be surprising. Stalin's early schooling in a Russian Orthodox seminary familiarised him with Orthodox dogma and liturgy and their interconnections; his speeches and writings sometimes reflected the logic and cadences he learnt then (on his career in the seminary, see (Kotkin 2014, pp. 31-38 and 45-47)).

Most of those involved in the physical creation of cultist infrastructure were not politically significant. Leading artists—such as Aleksandr Gerasimov, Dmitrii Nalbandyan and Vasilii Yefanov—and poster designers—such as Viktor Deni, Boris Yefimov and Gustav Klutsis-were major figures in the cultural establishment whose work was not restricted to direct cultist production, but apart from that they were not generally public proponents of 
the cult. This was not the case with regard to the political oligarchs, those leading politicians surrounding Stalin who all became leading public proponents of the cultist image. Lazar Kaganovich and Kliment Voroshilov were both very active in the early promotion of the cult; according to the oligarch Anastas Mikoyan, from an early time Kaganovich began to glorify Stalin whenever he spoke, thereby making it incumbent on the others to do the same unless they wanted to evoke Stalin's suspicions (Mikoyan 2014, p. 344), while Voroshilov was instrumental in organising the work of artists producing cultist materials (Plamper 2012, pp. 145-58). Generally the oligarchs were not always sycophantic in Stalin's presence, at times disagreeing with him even if ultimately they accepted his decisions ((Gill 2021, chp. 3); although on Malenkov dutifully writing down everything Stalin said, see (Mikoyan 2014, p. 633)). However, in public, they all appeared as major spokespeople for the cult. In their speeches and writings, they praised Stalin and the way in which his leadership was central to all Soviet successes. Nothing was too small not to be attributable to his leadership, guidance and solicitude. Their role in this was particularly clear on the occasions of the celebration of Stalin's 60th and 70th birthdays in 1939 and 1949. On both of these occasions, the party newspaper Pravda was saturated with messages of greeting to Stalin and articles about him and his leadership. Chief among these were articles by the leading oligarchs, which were then, sometimes in expanded form, published as booklets in very large print runs. It is clear that for leading political figures, part of their public responsibilities was to promote the cult and its principal, and while this was not formally written down anywhere, it was nonetheless mandatory if leading political figures wished to avoid getting on the wrong side of the "great leader".

However, in their public performances, the oligarchs did more than praise the figure of the leader: they helped to construct an intellectual framework designed to construct and monopolise public space in the country. Projection by the political leadership of an explicit framework had been a characteristic of the regime from its outset. Initially seen in terms of Marxism, with Lenin's death in 1924, this became transformed into Marxism-Leninism and was seen as the official ideology of the regime. This was especially important given that the Bolshevik aim was the creation of a secular society in which the church had no place, with the official ideology being seen in some sense as a replacement for religion. However, this was one which in theory had no dominant figure; the imperative of historical progress was class conflict, not the "great man". With the growth of the cult in the 1930s, the official ideology was transformed to take on a Stalinist form whereby the chief strand, even more important than Marx or Lenin, became Stalin's thoughts and writings; the "great man" became primary. The result was a doctrine designed to provide guidance for the country and its inhabitants, and if the people were not as in a religion expected to accept those words as holy writ, to be worshipped and treated as the word of God, they were expected to take them to heart and to follow their precepts. For the oligarchs, this meant publicly quoting from Stalin and declaring their commitment to the fulfilment of his instructions. For the populace too, these were imperatives, but unlike the oligarchs the occasions on which they were individually expected to stand up and publicly declare their commitment were rare events. More commonly, they were expected to take part in collective rituals that affirmed their belief and commitment. This is discussed below.

Not only the performative aspect of the monopolisation of public space by the intellectual framework emanating from the cult and reflected in the ubiquitous quotation of his words was important; the cognitive dimension was also significant. Like religious doctrine, Soviet ideology moulded into its Stalinist form by the cult represented an intellectual framework designed to offer a world view that its adherents could use to understand the world around them. Based on an historical eschatology rather than a set of ethical principles, it offered a set of concepts and a language which both framed current reality and legitimated the Soviet system and its teleology. The Russian language had undergone a revolutionary transformation following the 1917 revolution (Gorham 2003), with new concepts and words introduced to displace those that were no longer deemed either appropriate or useful. The new lexicon carried with it new conceptions of society and relationships within it and 
underpinned what was seen as a new "socialist" culture. With the rise of the cult, this emergent culture took on a Stalinist sheen (for example, Petrone 2000; Hoffmann 2003; Brooks 2000). Had Stalin not acceded to the position of dominant leadership he achieved and had the cult not therefore been so monopolistic of the public culture, many aspects of that culture would have been the same. For example, the emphasis on the building of socialism, on class as the primary category of social analysis, on freedom and equality would in all likelihood have remained as mainstays of Soviet public culture. What the cult did was to inject into this public culture some new elements-most importantly, Stalin as the indisputable authority figure-while emphasising elements that were already there, such as the ubiquity of enemies both inside and outside the country. The point about this intellectual framework is that it was meant to be internalised by the populace, to be accepted as the intellectual basis upon which their lives were grounded. That framework was meant to fundamentally drive people's behaviour by framing the way in which they understood the world. In this way, the cult was directly linked with behaviour in a subliminal way. However, it was also more openly linked through ritual.

\section{Soviet Ritual and the Cult}

Public performance was a central aspect of the Soviet regime, occurring both within the institutions of that regime and in the streets more generally. Turning first to the institutions of the regime, in the decade and a half following the revolution major decision-making organs of the party, the congress and the central committee, moved from being venues in which there was real discussion and debate to ones where the proceedings were formulaic, generally monolithic and uncritically affirmatory (The Politburo did not follow the same path until the 1930s, but because its deliberations were secret, its role was different. Gill (2018, chps. 2-4; 2021, chps. 2-3)). What the cult did was to inject the figure of Stalin into the symbolic matrix of these bodies' meetings. This is best seen with regard to the congress, the proceedings of which were published. These were large gatherings of party officials which met to hear speeches by leading party figures (usually plus some regional officials) and formally to adopt decisions on the major questions of the day. Illustrative of the emergence of the figure of Stalin into the dominant position in the performative dimension of the congress is a comparison of the opening of the Tenth Congress in 1921 and the Eighteenth Congress in 1939. The first session of the Tenth Congress was opened by Lenin calling on delegates to take their seats. This was greeted with "prolonged applause" (Desyatyi 1963, p. 1). At the opening session of the Eighteenth Congress, the appearance of the party leaders was said to be met with

"thunderous applause. From the different corners of the hall well up cries in all the languages of the peoples of the USSR in honour of the great Stalin: 'To the leader of the peoples-to the great Stalin-hooray!', 'Long live comrade Stalin!', 'To the dear, beloved Stalin-hooray!', 'Long live the Stalinist Central Committee!', 'Long live our leader and teacher-comrade Stalin!', 'Long live comrade Stalin!', 'Long live the first marshal of the army of communism-comrade Stalin!'”.

(XVIII s'ezd 1939, p. 3)

The main addresses to the two congresses were delivered, respectively, by Lenin and Stalin. Lenin's address in 1921 was preceded and followed by "Stormy applause" (Desyatyi 1963, pp. 21 and 40). Stalin's 1939 address was preceded by the following:

"Stormy ovation, standing the congress meets comrade Stalin. In all languages of the peoples of the great Soviet Union ring out cries 'Long live comrade Stalin!', 'Hooray', 'To the leader, teacher and friend, comrade Stalin-hooray!', 'Long live our dear, beloved Stalin!' The ovation lasts for a long time, an expression of the unlimited love of the whole party for its leader. The stormy applause greeting the congress drowns out the bell of the chairman."

Similar encomiums followed his speech: 
"All delegates rise, standing greet comrade Stalin and accord him a prolonged ovation. Calls of: 'Hooray! Long live comrade Stalin! Hooray to the great Stalin! Hooray to our beloved Stalin!'".

(XVIII s'ezd 1939, p. 38)

The difference between the two congresses could hardly be greater. At the Tenth Congress the greeting for the leading figure in the party is restrained, even polite. There is none of the excessive praise given to Stalin, nor was the figure of the speaker the main focus of the delegates' attention. What was important was what the leader was going to say or had said. In contrast, it is clear that by 1939 that both the opening of the congress and the presentation of the major speech were occasions for the laudation of the supreme leader, Stalin. He was the only speaker accorded such praise.

This characteristic of the party congress was also typical of all other official meetings, at least those held in public. Stormy applause was the response not only when Stalin appeared, but even when his name was mentioned. Additionally, his name appeared in all speeches in the late 1930s and post-war periods. According to a visitor to Moscow in 1937, "Any speeches which one may have the opportunity of hearing, not only political, but also lectures on any artistic and scientific subject, are interlarded with glorifications of Stalin ... " (Feuchtwanger 1937, p. 69). The British ambassador to Moscow in February 1935, Lord Chilston, captures the nature of such meetings:

"At the opening of the All-Union Congress of Soviets, a function which proved to be of little else than a glorification of the Leader, the two thousand delegates rose to their feet whenever the name of M. Stalin was mentioned, cheering and clapping and singing the Internationale, sometimes even for ten minutes. It was observable that no person dared to cease clapping, for fear that his neighbour should notice, until the speaker had resumed his seat as a signal for the ovation to end. On another occasion-the opening of an exhibition of theatrical art-a speaker realising when he had finished his speech that the due reference to M. Stalin as the father of the arts and drama of the new Russia had been forgotten, rushed pallid to the platform again and produced a panegyric ...".

(Foreign Office Records, "Viscount Chilston to Sir John Simon, 22 February 1935: N 1017/6/38" cited in Hyde (1971, pp. 317-18))

The conduct of all public meetings was thus fundamentally shaped by the cult with the primary purpose of the meeting often displaced by laudation of the leader. This ritualistic veneration of Stalin, undertaken by oligarchs, officials and ordinary people may be reminiscent of the sort of veneration present at revivalist religious meetings, but in the case of the leader cult that veneration often subverts the ostensible reason for and the business of the meeting whereas in religions this tends to be the primary aim of the gatherings.

The cult also shaped mass festivals characteristic of the Soviet regime, but principally through adding a veneer to what existed before. From the outset of Bolshevik rule mass festivals had been mounted as a means of both celebrating achievement and socialising the new population into the new revolutionary culture (on such early festivals, see Tolstoy et al. 1990; von Geldern 1993). This practice soon stabilised into a regular calendar, with the most important such festivals being those celebrating May Day and the anniversary of the revolution on 7 November. These celebrations developed in form over time (for their early development, see Gill 2011, pp. 70-73) with the key element of both a march through Red Square; similar marches were held in other cities as well, but the Moscow one was the most important. Involving a changing mix of civilian and military marchers, these were marked by the carrying of placards, chiefly bearing revolutionary slogans, and the mass shouting of slogans. From the May Day celebration of 1924, the first following Lenin's death, pictures of the leaders and especially Lenin were very prominent among the placards; big pictures of leaders also appeared on the walls of buildings, especially on the route of the march. With the dominance of the cult in the 1930s, the balance among such 
pictures changed. It was usual for all of the leading figures of the regime to be depicted in such pictures, but from the 1930s images of Stalin were predominant. Among the sea of red banners, Stalin's image rose supreme. Similarly, in the shouts emanating from the throats of the marchers, "Long live comrade Stalin!" became the key. The image of Stalin became so pervasive in these celebrations that it soon appeared to many to be a moot point as to whether they were celebrating May Day and the Revolution or the "great leader".

A similar process occurred in numerous other types of activities common in Soviet society. Meetings in factories and farms, ceremonies to mark the beginning of the school year or final graduation, meetings to laud stakhanovites and their achievements, celebrations of economic and civic achievements, public assemblies to congratulate high achievers such as polar explorers and Soviet airmen, even the lauding of mothers for producing numerous children, were all public performances whose original intent became transformed into a celebration of Stalin. This was manifested in their being conducted under the gaze of Stalin, usually through a picture of him on the wall, and through frequent references to Stalin, especially in the form of attributing whatever triumph was being celebrated to his wise and loving leadership. Collective oaths to Stalin were often given at such meetings, especially of such groups as members of the Soviet youth organisations the Young Pioneers and the Komsomol and at meetings in the armed forces. The civic rituals conducted by the regime were thereby reshaped into rituals about Stalin and his leadership.

On a more intimate level too, the cult wrought change. In pre-revolutionary Russian homes, particularly among the peasantry, there was a so-called "Red Corner" where icons, other religious artefacts, and sometimes images of the tsar were placed. These were seen as the locus of devotion in the home. Following the revolution such Red Corners, found not only in citizens' homes but also in workplace dormitories, took on a Soviet hue (for an example from a workers' dormitory in Magnitogorsk, see (Kotkin 1995, p. 180)). The icons, religious artefacts and images of the tsar were replaced by pictures initially principally of Lenin. With Stalin's emergence as the dominant figure in the regime, his picture appeared here too, often ousting that of Lenin as the main image. Similarly, his picture appeared in all offices across the land as his face became the face of the regime.

However, did these changes in ritual really affect people's actions? Clearly participation in the sorts of meetings noted above involved individuals in giving public, collective, recognition of Stalin and his leadership. It constituted recognition of his authority and perhaps love of his person. The popular veneration of Stalin was mainly indirect through such meetings and the presence at them of Stalin's image. Certainly, those marching across Red Square came into direct, if distant, contact with Stalin standing on the Lenin Mausoleum in front of the Kremlin. However, this was the only real opportunity for rank-and-file Soviet citizens to come into contact with the great leader (of course party members got closer to Stalin, especially when he was addressing them), although some specially chosen ones may have been invited to receptions such as those held for the returned polar explorers. Despite the imagery suggested in much cultist art (for example, see the painting "An Unforgettable Encounter" by Vasilii Yefanov in (Groys and Hollein 2003, pp. 146-47) where Stalin, surrounded by the other leaders, shakes hands with a normal Soviet woman), Stalin rarely met with ordinary citizens. He generally avoided the public stage except on major occasions, and for most citizens remained a remote figure. Their interactions with him were mediated through the ritualised processes of public performance when they participated in meetings and other public events or through the reading of his words. Individuals may have personally communed with Stalin, giving him private thanks or encouraging their children to accept his authority, but we know neither the frequency with which this occurred nor the intensity of feeling that may have underpinned it. All we really have is the public manifestations of devotion and speculation about how genuine the feelings were that were on show at that time.

If it is not clear that the changes in ritual affected people's private as opposed to their public behaviour, what is certain is that the emergent Stalinist Soviet public culture shaped the consciousness of Soviet citizens. In any society, people are socialised by a 
range of influences, with the public culture being a central one of these. This is usually overwhelmingly an unconscious process; the education system, the workplace, the media and the home environment shape the values individuals hold. In the Soviet Union, this was a conscious aim of the authorities, to replace what were seen as "bourgeois" values by the "proletarian" values that would be consistent with the achievement of socialism. Furthermore there could also be an element of consciousness on the part of individuals as many of them consciously set out to mould themselves in accord with the values being espoused by the regime (see the analysis based on personal diaries in (Hellbeck 2006)). What this means is that the Stalinist public culture, what Kotkin (1995) has called "Stalinist civilization", shaped people's values and thereby their actions. However, this public culture is far greater than the Stalin cult, and so although that cult will have contributed to the shaping of the so-called "new Soviet man", it did so as part of the broad sweep of Soviet culture.

\section{A Political Religion?}

So does this help us in understanding whether the cult should be seen as a political religion (for the argument that the cult was a secularised version of the Russian Orthodox veneration of saints and a version of the "good ruler bad officials" batyushka tsar myth, see The Leader's Many Bodies: Leader Cults and Mass Festivals in Voronezh, Novosibirsk, and Kemerovo in the 1930s in (Heller and Plamper 2004, p. 198))? There are a number of aspects of the cult that appear to be analogues of aspects of the Christian religion. There is a personified object of veneration in the figure of Stalin (although whether as an analogue of the son or the father is ambiguous) and a group of people (the oligarchs) who proselytised the cultist message like the apostles (although they did have other jobs that were more important than their role as purveyors of the cultist message). There was also a group of officials distributed throughout the country (for example, regional party leaders) whose task was in part to sustain the cultist message and officials at the centre who were responsible for shaping that message, analogues of both the Russian Orthodox Church with its clergy distributed in parishes and its central administration in the Holy Synod and the Roman Catholic church-based priests and the central administration in the Vatican. The cultist message promised a type of salvation in the form of escape from an unjust present and achievement of a better future, but unlike those religions where salvation occurred in the afterlife, this was to be achieved on earth through the construction of a new socialist and then communist society. Both were eschatological and sought to create a belief system that would override or displace all others. There was also a written corpus, and although not concentrated in one central volume (like the Bible), the basic texts were established (if not unchanging) and widely available. The cult did try, like religion, to create a community of believers. Additionally, those who disagreed were treated like heretics.

However, there were also significant differences. A key one concerns the site of salvation, the afterlife compared with the communist future, noted above. Major differences occurred in the area of liturgy or ritual. In the religion, there were various elaborate rituals to be followed at each life stage (birth, confirmation, marriage, and death) as well as in the regular, usually weekly, meetings for worship. Believers were also expected to pray on a regular basis, with some standardised prayers alongside the more spontaneous ones individuals were to devise as part of their worship. Additionally, regular ceremonies of worship were conducted in sites especially reserved for this activity and by professional officials whose task was leading such activity (churches and priests/ministers). There is little in the way of cultic counterparts, although paradoxically Stalin's birthday was the occasion for the widespread presentation of gifts to him. The cult, as opposed to Soviet civic culture, did not have elaborate rituals for the life stages nor regular occasions specifically and solely for the veneration of the leader except his birthday. There were no standardised prayers to the leader, although there were odes and poems to him and individuals may have personally asked for things, but there was no established method of prayer. Nor were there specific sites set aside purely for cultic activity nor a large number of people whose 
professional activity was restricted to promotion of the cult. Those sites of cultic ritualistic activity were actually sites for the realisation of the basic Soviet public culture. They gained a cultic veneer when the cult was dominant, but when it disappeared they continued on without the cultic attachments.

Thus, while there are aspects of the leader cult and its realisation that bear close comparison with religion, most ritualistic aspects of religion find no direct counterpart in the cult (this is consistent with the finding by Leader Cults: Varieties, Preconditions and Functions in (Apor et al. 2004, p. 17)) that the Stalin cult lacked the ritualisation of the Nazi leader cult). Accordingly, while the idea of political religion does have a superficial attraction, and may in fact accord with the aspirations of some of those who promoted the Stalin cult, it does need to be used with care. It is probably less useful than seeing the cult in terms of an attempt to create a charismatic relationship between the principal of the cult (Stalin) and the followers. Such an interpretation does not deny religious overtones because, as the chief theorist of charisma Max Weber acknowledges, charisma does have religious overtones.

Funding: This research received no external funding.

Institutional Review Board Statement: Not applicable.

Informed Consent Statement: Not applicable.

Data Availability Statement: Not applicable.

Conflicts of Interest: The author declares no conflict of interest.

\section{References}

Apor, Balazs, Jan C. Behrend, Polly Jones, and E. Arfon Rees, eds. 2004. The Leader Cult in Communist Dictatorships. Stalin and the Eastern Bloc. Basingstoke: Palgrave Macmillan.

Arendt, Hannah. 1986. The Origins of Totalitarianism. London: Andre Deutsch. First published 1951.

Brooks, Jeffrey. 2000. Thank You Comrade Stalin! Soviet Public Culture from Revolution to Cold War. Princeton: Princeton University Press. Desyatyi s'ezd RKP(b). Mart 1921 goda. Stenograficheskii Otchet. 1963. Moscow: Gosudarstvennoe Izdatel'stvo Politicheskoi Literatury.

Feuchtwanger, Lion. 1937. Moscow 1937. My Visit Described for My Friends. Translated by Irene Josephy. New York: The Viking Press.

Friedrich, Carl J., and Zbigniew K. Brzezinski. 1965. Totalitarian Dictatorship and Autocracy. Cambridge: Harvard University Press. First published 1956.

Gill, Graeme. 2011. Symbols and Legitimacy in Soviet Politics. Cambridge: Cambridge University Press.

Gill, Graeme. 2018. Collective Leadership in Soviet Politics. Cham: Palgrave Macmillan.

Gill, Graeme. 2021. Bridling Dictators. Rules and Authoritarian Politics. Oxford: Oxford University Press.

Gorham, Michael S. 2003. Speaking in Soviet Tongues. Language Culture and the Politics of Voice in Revolutionary Russia. Dekalb: Northern Illinois University Press.

Griffin, Roger, ed. 2005. Fascism, Totalitarianism and Political Religion. London: Routledge.

Groys, Boris, and Max Hollein. 2003. Dream Factory Communism. The Visual Culture of the Stalin Era. Frankfurt: Hatje Cantz.

Hellbeck, Jochen. 2006. Revolution on My Mind. Writing a Diary under Stalin. Cambridge: Harvard University Press.

Heller, Klaus, and Jan Plamper, eds. 2004. Personality Cults in Stalinism. Gottingen: V\&R unipress.

Hoffmann, David L. 2003. Stalinist Values. The Cultural Norms of Soviet Modernity. Ithaca: Cornell University Press.

Hyde, H. Montgomery. 1971. Stalin. The History of a Dictator. London: Rupert Hart-Davis.

Kotkin, Stephen. 1995. Magnetic Mountain. Stalinism as a Civilization. Berkeley: University of California Press.

Kotkin, Stephen. 2014. Stalin. Volume 1. Paradoxes of Power, 1878-1928. New York: Penguin Press.

Kurz, Angela Astoria. 2009. God not Caesar: Revisiting National Socialism as Political Religion. History of European Ideas 35: $236-52$. [CrossRef]

Maier, Hans. 2007. Political Religion: A Concept and its Limitations. Totalitarian Movements and Political Religions 8: 5-16. [CrossRef] Mikoyan, Anastas Ivanovich. 2014. Tak bylo. Razmyshleniya i minuvshem. Moscow: Tsentropoligraf.

Petrone, Karen. 2000. Life Has Become More Joyous, Comrades. Celebrations in the Time of Stalin. Bloomington: Indiana University Press. Pisch, Anita. 2016. The Personality Cult of Stalin in Soviet Posters, 1929-1953. Archetypes, Inventions and Fabrications. Canberra: ANU Press.

Plamper, Jan. 2012. The Stalin Cult. A Study in the Alchemy of Power. New Haven: Yale University Press.

Roberts, David D. 2020. Totalitarianism. Cambridge: Polity Press.

Schapiro, Leonard. 1972. Totalitarianism. London: Macmillan. 
Tikhomirov, Alexey. 2021. Father of the people, face of the nation: The premodern and modern foundations of ruler personality cults. In Ruler Personality Cults from Empires to Nation-States and Beyond. Symbolic Patterns and Interactional Dynamics. Edited by Kirill Postoutenko and Darin Stephanov. London: Routledge, pp. 120-42.

Tolstoy, Vladimir, Irina Bibikova, and Catherine Cooke. 1990. Street Art of the Revolution. Festivals and Celebrations in Russia 1918-33. New York: The Vendome Press.

Voegelin, Eric. 1986. Political Religions. Translated by T. J. Di Napoli, and E. S. Easterly III. Lewiston: E. Mellen Press. First published 1938.

von Geldern, James. 1993. Bolshevik Festivals 1917-1920. Berkeley: University of California Press.

Weber, Max. 1978. Economy and Society. An Outline of Interpretive Sociology. Berkeley: University of California Press. First published 1922.

XVIII S'ezd Vsesoiuznoi Kommunisticheskoi Partii (b). 10-21 Marta 1939g. Stenograficheskii Otchet. 1939. Moscow: Gosudarstvennoe Izdatel'stvo Politicheskoi Literatury. 